\title{
Nitrosocarbonyl Release from $O$-Substituted Hydroxamic Acids with Pyrazolone Leaving Groups
}

\author{
Saghar Nourian, Robert P. Lesko, Daryl A. Guthrie, and John P. Toscano* \\ Department of Chemistry, 3400 North Charles Street, Johns Hopkins University, Baltimore, \\ Maryland 21218, United States
}

This article is dedicated to Professor Gary H. Posner in appreciation of his career contributions to organic chemistry.

\begin{abstract}
A new class of nitrosocarbonyl precursors, $O$-substituted hydroxamic acids with pyrazolone leaving groups (OHPY), is described. These compounds generate nitrosocarbonyl intermediates, which upon hydrolysis release nitroxyl (azanone, HNO) under physiologically relevant conditions. Pyrazolones have been used to confirm the generation of nitrosocarbonyls by competitive trapping to form isomeric $N$-substituted hydroxamic acids (NHPY) via an $N$-selective nitrosocarbonyl aldol reaction. The rate of nitrosocarbonyl release from OHPY donors is impacted by donor substituents, including the pyrazolone leaving group.
\end{abstract}

Keywords: nitrosocarbonyl; nitroxyl; HNO; pyrazolone

* Corresponding author. Tel.: +1-410-516-6534; fax: +1-410-516-8420; e-mail: jtoscano@jhu.edu 


\section{Introduction}

Nitroxyl (azanone, HNO), the one-electron reduced and protonated form of nitric oxide, has been shown to improve both vasorelaxation and myocardial contractility, making $\mathrm{HNO}$ donors ideal candidates for drug development. ${ }^{1-9}$ HNO is a reactive molecule that spontaneously dimerizes to produce hyponitrous acid $(\mathrm{HON}=\mathrm{NOH})$, which then dehydrates to give nitrous oxide $\left(\mathrm{N}_{2} \mathrm{O}\right) .{ }^{10}$ Due to this inherent reactivity, HNO must be generated in situ through the use of donor compounds.

Angeli's salt $\left(\mathrm{Na}_{2} \mathrm{~N}_{2} \mathrm{O}_{3}\right.$, AS, Fig. 1) is a well-known donor that generates $\mathrm{HNO}$ under physiological conditions with a short half-life. ${ }^{11}$ Derivatization of this inorganic salt has been unsuccessful to date, thus preventing modification for tunable HNO release. Piloty's acid (PA) derivatives and acyloxy nitroso compounds (AcON) represent other types of HNO donors that have been developed with tunable half-lives. ${ }^{12-17}$ Our group has recently reported two new series of HNO donors with half-lives that can be varied from minutes to hours under physiological conditions: (hydroxylamino)pyrazolone (HAPY) and (hydroxylamino)barbituric acid (HABA) derivatives. ${ }^{18-20}$ In addition to these examples, the continued development of efficient HNO donors is important to expand the research tools available to understand the potential role of HNO in biological processes.

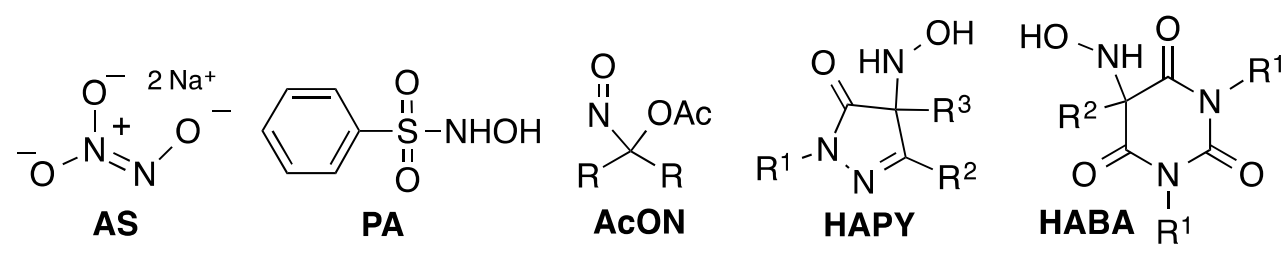

Fig. 1. Some previously reported HNO donors. 
Another strategy to release $\mathrm{HNO}$ is based on the hydrolysis of nitrosocarbonyl intermediates..$^{21-22}$ Nitrosocarbonyls are highly reactive species that can react with nucleophiles including water to generate HNO. Oxidation of hydroxamic acids and thermal decomposition of 9,10-dimethylanthracene adducts represent common approaches to nitrosocarbonyl generation..$^{23-25}$ The photolysis of nitrodiazo compounds, nitronates with alpha leaving groups, and 1,2,4-oxadiazole-4-oxides have also been shown to generate nitrosocarbonyls efficiently. ${ }^{26-28}$ Recently, the aerobic oxidation of hydroxamic acids by metal catalysts under mild conditions has been developed as an efficient strategy for nitrosocarbonyl generation. ${ }^{29-46}$ In general, however, the above methods are not suitable for HNO generation under physiological conditions.

Herein, we report a novel class of nitrosocarbonyl donors that upon deprotonation and loss of the leaving group (Scheme 1, HX = pyrazolone) generate nitrosocarbonyl intermediates that can hydrolyze to release $\mathrm{HNO}$ under physiological conditions. As has been demonstrated in recent reports, ${ }^{33,35,36,40-42,45}$ nitrosocarbonyls can react with nucleophiles through an $\mathrm{N}$-selective nitrosocarbonyl aldol reaction to produce $\mathrm{N}$ substituted hydroxamic acid adducts. We have recently found that pyrazolones are efficient traps for nitrosocarbonyl intermediates to generate $N$-substituted hydroxamic acid derivatives with pyrazolone leaving groups (NHPY) in a reversible manner. ${ }^{47}$ In the current work, we observe OHPY decomposition to generate nitrosocarbonyls which further react with pyrazolones to produce isomeric NHPY compounds (Scheme 1). We have synthesized and studied NHPY compounds independently, and have recently demonstrated the efficient formation of nitrosocarbonyl intermediates upon decomposition of these compounds. ${ }^{47}$ 


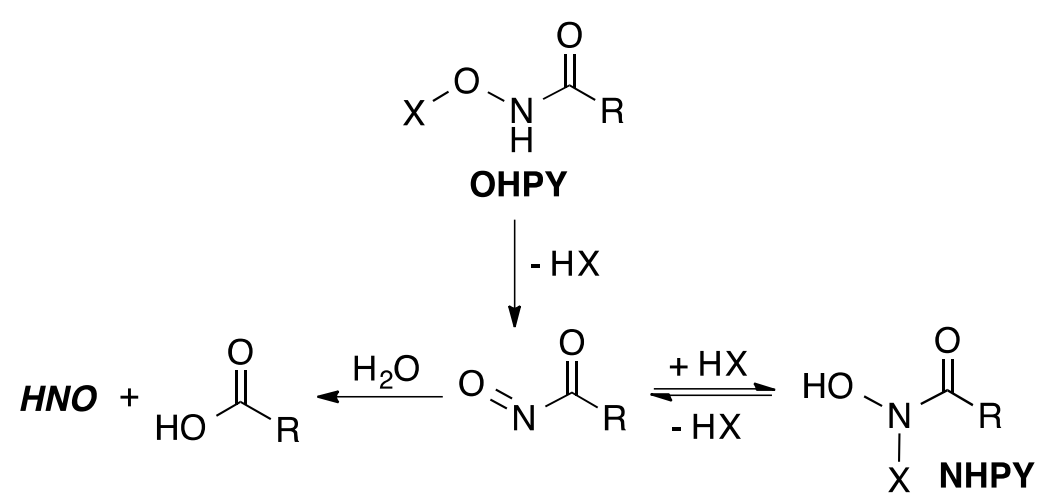

Scheme 1. Reactivity of OHPY nitrosocarbonyl precursors

\section{Results and Discussion}

\subsection{Synthesis}

OHPY compounds 1 have been synthesized by formation of the corresponding bromide (Br-PY) followed by reaction with hydroxamic acids (Scheme 2). Initially, OHPY 1a was synthesized without the need for chromatographic purification, and its structure was confirmed by X-ray crystallography (Supporting Information). The other precursors were purified using column chromatography.

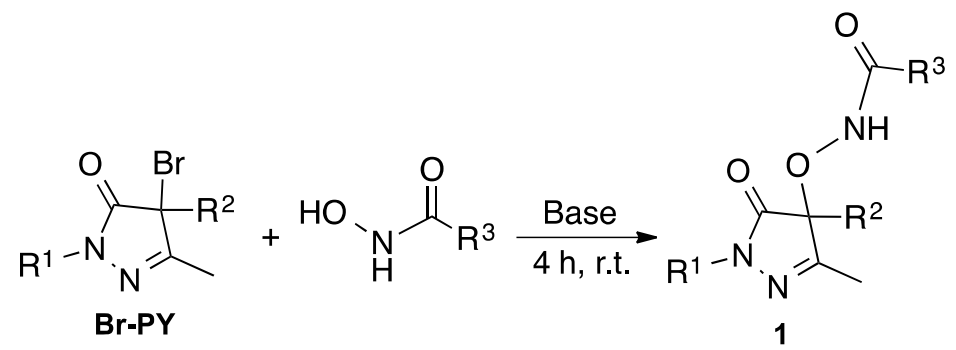

Scheme 2. Synthesis of OHPY derivatives

The OHPY and NHPY isomers can obviously be distinguished by X-ray crystallography. An analysis of ${ }^{13} \mathrm{C}$ NMR data and available crystal structures (Supporting Information), reveal that OHPY and NHPY compounds have distinctive 
chemical shifts for their quaternary carbons $(\delta=87.6-90.2 \mathrm{ppm}$ for OHPY vs. $\delta=68.4$ - $76.5 \mathrm{ppm}$ for NHPY). Thus, ${ }^{13} \mathrm{C}$ NMR spectroscopy conveniently allows the two isomers to be distinguished if crystal structures cannot be obtained.

\subsection{Decomposition of OHPY compounds}

Nitrosocarbonyl formation following OHPY decomposition under physiological conditions was studied. As described above, the reaction of nitrosocarbonyls and pyrazolones to produce NHPY compounds can be efficient. Upon nitrosocarbonyl generation from OHPY precursors $\mathbf{1}$, therefore, a competition exits between hydrolysis to generate HNO and carboxylic acid 4 (Scheme 3, Path A) and trapping by the pyrazolone byproduct 2 to produce NHPY compounds 3 (Scheme 3, Path B). NHPY compounds subsequently can also release nitrosocarbonyl intermediates with half-lives that depend on $\mathrm{R}^{1}, \mathrm{R}^{2}$, and $\mathrm{R}^{3}$ (Scheme 3, Path C). ${ }^{47}$

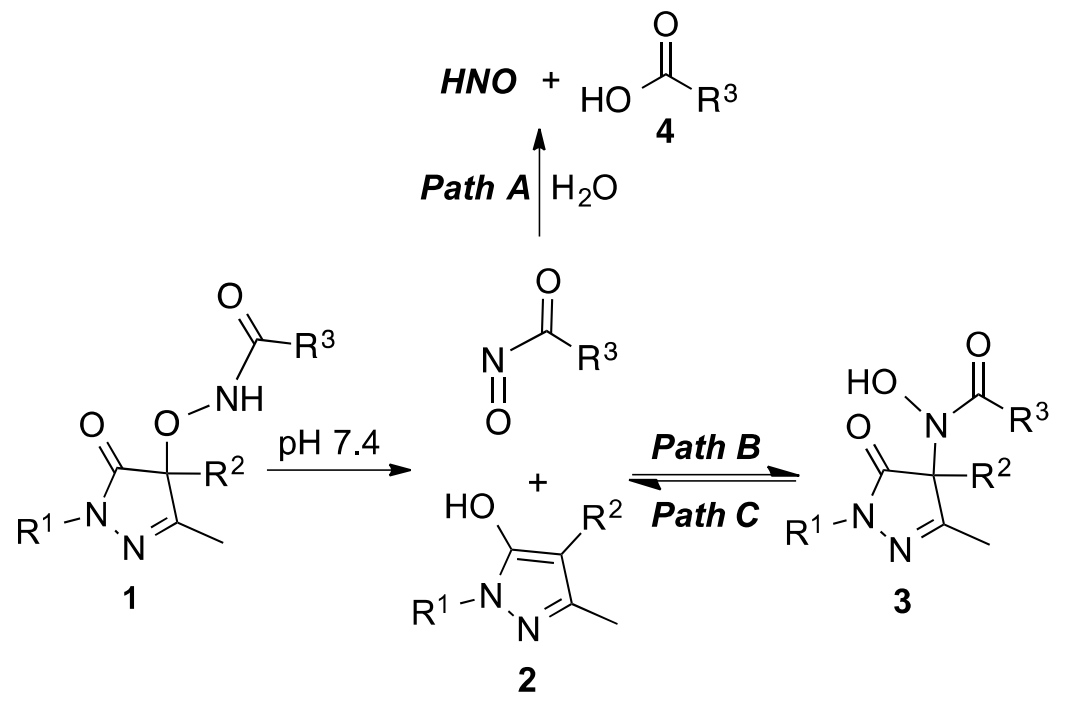

Scheme 3. Reactivity of OHPY donors 1 
${ }^{1} \mathrm{H}$ NMR spectroscopy was used to examine the decomposition of OHPY donors and measure relative product yields in aqueous solution (Table 1). ${ }^{19,20}$ Pyrazolone 2 , NHPY 3, and carboxylic acid $\mathbf{4}$ are cleanly formed as the only observable organic products. Because NHPY compounds 3a, 3c, and 3d all have half-lives on the order of days, ${ }^{47}$ Path $C$ in Scheme 3 does not contribute to the observed chemistry for OHPY donors 1a, 1c, and 1d. Thus, the relative yields of pyrazolone $\mathbf{2}$ and carboxylic acid $\mathbf{4}$ compared with that for NHPY compound $\mathbf{3}$ in Table 1 reflect the competition between Path $A$ and Path $B$ for these donors.

Table 1. Product yields and half-lives for OHPY donors

\begin{tabular}{cccccccc}
\hline OHPY & $\mathbf{R}^{\mathbf{1}}$ & $\mathbf{R}^{\mathbf{2}}$ & $\mathbf{R}^{\mathbf{3}}$ & $\mathbf{\% 2}^{\boldsymbol{a}}$ & $\mathbf{0 3}^{\boldsymbol{a}}$ & $\mathbf{0 4}^{\boldsymbol{a}}$ & $\boldsymbol{t}_{\mathbf{1} \mathbf{2}} \mathbf{( m i n}^{\boldsymbol{b}}$ \\
\hline $\mathbf{1 a}$ & $\mathrm{Ph}$ & $\mathrm{C}(=\mathrm{NOMe}) \mathrm{Me}$ & $\mathrm{Me}$ & 74 & 26 & 73 & 25 \\
$\mathbf{1 b}$ & $\mathrm{Ph}$ & $\mathrm{Me}$ & $\mathrm{Me}$ & & & & $\mathrm{Stable}^{c}$ \\
$\mathbf{1 c}$ & $\mathrm{Ph}$ & $\mathrm{C}(=\mathrm{NOMe}) \mathrm{Me}$ & $\mathrm{MeO}$ & 28 & 72 & 27 & 0.6 \\
$\mathbf{1 d}$ & $\mathrm{Me}$ & $\mathrm{C}(=\mathrm{NOMe}) \mathrm{Me}$ & $\mathrm{MeO}$ & 14 & 86 & 14 & 1.2 \\
$\mathbf{1 e}$ & $\mathrm{Ph}$ & $\mathrm{C}(=\mathrm{NOMe}) \mathrm{Me}$ & $t-\mathrm{BuO}$ & $d$ & $d$ & $d$ & $d$ \\
\hline
\end{tabular}

${ }^{a}$ Relative yields determined from ${ }^{1} \mathrm{H}$ NMR analysis of the complete decomposition of $0.5 \mathrm{mM}$ of the OHPY donor in $10 \%$ DMSO- $\mathrm{d}_{6}, 10 \% \mathrm{D}_{2} \mathrm{O}$, and $80 \% \mathrm{H}_{2} \mathrm{O}$, phosphate

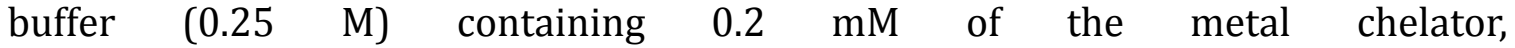
diethylenetriaminepentaacetic acid (DTPA), $\mathrm{pH} 7.4$ at $37{ }^{\circ} \mathrm{C}$ under argon. ${ }^{b}$ Determined by UV-vis spectroscopy. ${ }^{c}$ Less than $5 \%$ decomposition after 2 days. ${ }^{d}$ Not Determined due to low solubility.

OHPY decomposition was also monitored by UV-vis spectroscopy to measure donor half-lives at $\mathrm{pH} 7.4$ and $37^{\circ} \mathrm{C}$ (Table 1). Based on the chemistry of related HNO donors, ${ }^{19,20}$ we propose that the first step of decomposition is deprotonation which leads to release of nitrosocarbonyl plus pyrazolone. If the barrier to dissociation from anionic 
OHPY is very small, observed half-lives should correlate with donor $\mathrm{p} K_{\mathrm{a}}$ and the pyrazolone leaving group. ${ }^{19,20}$ Pyrazolone $\mathbf{2 a}\left(\mathrm{R}^{1}=\mathrm{Ph}, \mathrm{R}^{2}=\left(\mathrm{C}(=\mathrm{NOMe}) \mathrm{Me}, \mathrm{p} K_{\mathrm{a}}=6\right)\right.$ is a better leaving group than pyrazolone $\mathbf{2 b}\left(\mathrm{R}^{1}=\mathrm{Ph}, \mathrm{R}^{2}=\mathrm{Me}, \mathrm{p} K_{\mathrm{a}}=7.6\right),{ }^{19}$ consistent with the much shorter half-life for OHPY 1a $\left(t_{1 / 2}=25 \mathrm{~min}\right)$ compared with $\mathbf{1 b}$ (stable). Exchanging the $\mathrm{R}^{1}$ group from phenyl to methyl (OHPY 1c vs. 1d) increases the half-life by a factor of two, consistent with that previously reported for analagous HAPY and NHPY donors. ${ }^{19,47}$ A comparison of the known $\mathrm{p} K_{\mathrm{a}}$ values of the related compounds, $\mathrm{PhC}(\mathrm{O}) \mathrm{NHOH}(8.8)$ and $\mathrm{PhOC}(\mathrm{O}) \mathrm{NHOH}(10.0),{ }^{48}$ indicates that the $\mathrm{pK}$ a of OHPY 1a is likely lower than that of OHPY 1c. Although these two donors have the same pyrazolone leaving group, the longer half-life for OHPY 1a $\left(t_{1 / 2}=25 \mathrm{~min}\right)$ compared with $1 \mathbf{c}\left(t_{1 / 2}=\right.$ 0.6 min) suggests that the barrier to dissociation may also affect the observed half-lives. In the case of NHYP donors, the dissociation barrier was found to be strongly dependent on the $\mathrm{R}^{3}$ group. ${ }^{47}$ The origin and impact of the $\mathrm{R}^{3}$ group on OHPY dissociation requires further investigation.

HNO generation was examined by gas chromatographic (GC) headspace analysis to quantify the amount of its dimerization product, $\mathrm{N}_{2} \mathrm{O}$, formed following decomposition of OHPY donors in $\mathrm{pH} 7.4$ phosphate buffer solutions at $37{ }^{\circ} \mathrm{C}$ (Table 2). The amount of HNO release was measured relative to standard HNO donor, Angeli's salt. As expected, HNO yields from OHPY donors are consistent with the corresponding yields of pyrazolone $\mathbf{2}$ and carboxylic acid $\mathbf{4}$ observed under the same conditions. 
Table 2. HNO yields for OHPY donors at different concentrations

\begin{tabular}{cccc}
\hline \multirow{2}{*}{ OHPY } & \multicolumn{3}{c}{ \% HNO $^{\boldsymbol{a}}$} \\
\cline { 2 - 4 } & $\mathbf{5 0 0} \mu \mathbf{M}$ & $\mathbf{1 0 0} \mu \mathbf{M}$ & $\mathbf{2 0} \mu \mathbf{M}$ \\
\hline 1a & 70 & 75 & 91 \\
$\mathbf{1 b}$ & $b$ & $b$ & $b$ \\
$\mathbf{1 c}$ & 20 & 29 & 41 \\
$\mathbf{1 d}$ & 8 & 17 & 29 \\
$\mathbf{1 e}$ & $c$ & 26 & $35^{d}$ \\
\hline
\end{tabular}

${ }^{a}$ HNO yields are measured after complete decomposition of the donor and are reported relative to the standard $\mathrm{HNO}$ donor, Angeli's salt, as determined by $\mathrm{N}_{2} \mathrm{O}$ headspace analysis (SEM $\pm 5 \% ; n=3)$. ${ }^{b}$ Stable. ${ }^{c}$ Not determined due to low solubility. ${ }^{\mathrm{d}} t_{1 / 2}=3.2 \mathrm{~min}$ (measured using UV-vis spectroscopy).

The competition between nitrosocarbonyl hydrolysis to HNO (Path A) and pyrazolone trapping (Path B) depends on the relative concentration of pyrazolone. Lower concentrations of pyrazolone $\mathbf{2}$ following decomposition of lower concentrations of OHPY 1 will disfavor NHPY formation and correspondingly increase the yield of HNO. Determination of HNO yields at different concentrations of donors (Table 2), confirms that the yield of HNO is impacted as expected.

\subsection{Mechanistic Studies}

Our proposed mechanism for OHPY decomposition involves deprotonation followed by initial formation of a nitrosocarbonyl intermediate. Pyrazolone $\mathbf{2 b}$ has recently been demonstrated to be an efficient trap for nitrosocarbonyls under physiological conditions. ${ }^{47}$ To confirm the formation of nitrosocarbonyls upon OHPY decomposition, we incubated OHPY $1 \mathbf{a}(0.5 \mathrm{mM})$ in presence of pyrazolone $2 \mathbf{b}(0.5 \mathrm{mM})$ in $\mathrm{pH} 7.4$ phosphate buffer at $37^{\circ} \mathrm{C}$ (Scheme 4). Upon decomposition of donor 1a under 
these conditions, we observe quantitative formation of NHPY $3 \mathbf{b}$ (Supporting Information), strong evidence for nitrosocarbonyl formation.

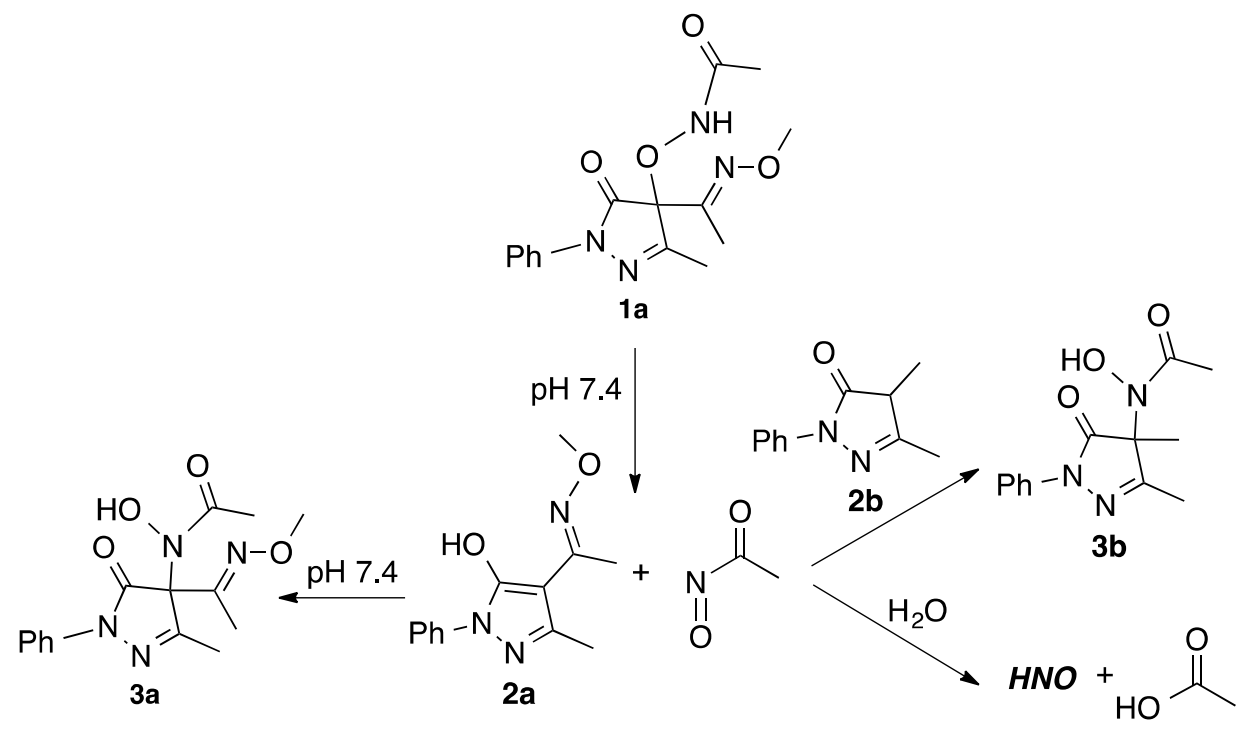

Scheme 4. Reactivity of OHPY $\mathbf{1 a}$ in the presence of pyrazolone $\mathbf{2 b}$

In the absence of pyrazalone $\mathbf{2 b}$, the decomposition of OHPY 1a provides NHPY 3a $(26 \%)$ (which has a half-life of 5 days), and $\mathrm{HNO}(70 \%)$ and acetate $(73 \%)$ (Scheme 4 and Tables 1,2). The stability of NHPY 3a, along with the observation that it is not formed in the presence of pyrazolone $\mathbf{2} \mathbf{b}$, also argues against the possibility of a direct intramolecular rearrangement from anionic OHPY 1a to NHPY 3a without involvement of a nitrosocarbonyl intermediate.

Based on reactivity studies of bis-heteroatom-substituted amides, ${ }^{49}$ the formation of NHPY $\mathbf{3 b}$ may be possible through the direct attack of pyrazolone $\mathbf{2} \mathbf{b}$ on the amide nitrogen of the hydroxamic acid moiety of NHPY 3a (Scheme 5). To examine this possibility, NHPY 3a was incubated with pyrazolone $\mathbf{2 b}$ and its stability was confirmed by ${ }^{1} \mathrm{H}$ NMR spectroscopy at $\mathrm{pH} 7.4$ and 10 . The $\mathrm{pK}$ a of NHPY 3a has recently been 
measured to be 10.0 and its stability at or above $\mathrm{pH} 10$ suggests a relatively high barrier for nitrosocarbonyl formation from this NHPY donor even when deprotonated. ${ }^{47}$

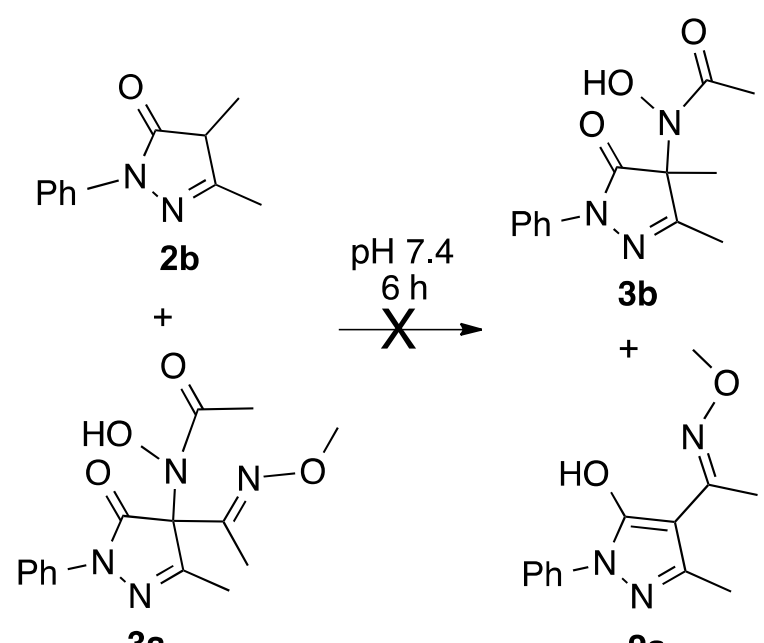

Scheme 5. The possible reaction of NHPY 3a with pyrazolone $\mathbf{2 b}$

\section{Conclusions}

The OHPY class of nitrosocarbonyl precursors efficiently generates these intermediates under physiological conditions following deprotonation and loss of pyrazolone. The nitrosocarbonyl produced is subsequently hydrolyzed to HNO in competition with trapping by the pyrazolone byproduct via an $N$-selective nitrosocarbonyl aldol reaction to form an isomeric NHPY compound. The rate of nitrosocarbonyl release from OHPY compounds in aqueous solution is dependent on the pyrazolone leaving group. This rate is also influenced by the $\mathrm{R}^{3}$ substituent, an effect that is under current investigation. 


\section{Experimental Section}

\subsection{Method and Materials}

All starting materials were of reagent grade and used without further purification. $N$-hydroxy- $N$-(4-(acetyl-O-methoxyoxime)-3-methyl-5-oxo-1-phenyl-4,5-dihydro- $1 H$ pyrazol-4-yl)- $N$-acetamide (NHPY 3a), N-hydroxy- $N$-(4-(acetyl-O-methoxyoxime)-3methyl-5-oxo-1-phenyl-4,5-dihydro-1H-pyrazol-4-yl)- $N$-methylcarbamate (NHPY 3c), $N$-hydroxy- $N$-(4-(acetyl-O-methoxyoxime)-1,3-dimethyl-5-oxo-4,5-dihydro-1H-pyrazol4-yl)- $N$-methylcarbamate (NHPY 3d), ${ }^{47}$ 4-(acetyl-O-methoxyoxime)-3-methyl-1-phenylpyrazolone 2a, 3,4-dimethyl-1-phenyl-pyrazolone 2b, 4-(acetyl-O-methoxyoxime)-1,3dimethylpyrazolone $\quad 2 c{ }^{19} \quad$ 4-(acetyl-O-methoxyoxime)-4-bromo-3-methyl-1-phenylpyrazolone , 4-bromo-3,4-dimethyl-1-phenyl-pyrazolone, 4-(acetyl-O-methoxyoxime)-4bromo-1,3-dimethyl-pyrazolone, ${ }^{18}$ C-methoxycarbohydroxamic acid, and tertbutylhydroxycarbamate $^{50}$ were prepared according to literature procedures. Acetohydroxamic acid was purchased and used without further purification. NMR spectra were obtained on a $400 \mathrm{MHz}$ FT-NMR spectrometer. All chemical shifts are reported in parts per million (ppm) relative to residual $\mathrm{CHCl}_{3}\left(7.26 \mathrm{ppm}\right.$ for ${ }^{1} \mathrm{H}, 77.23$ ppm for ${ }^{13} \mathrm{C}$ ). High-resolution mass spectra were collected on a magnetic sector mass spectrometer working in fast atom bombardment (FAB) mode. Gas chromatography (GC) headspace analysis was performed on the instrument equipped with ECD detection and a molecular sieve packed column. Ultraviolet-Visible (UV-vis) absorption spectra were collected using a diode array spectrophotometer. 


\subsection{Synthesis}

General procedure for the synthesis of N-((4-(acetyl-O-methoxyoxime)-3-methyl5-oxo-1-phenyl-4,5-dihydro-1H-pyrazol-4-yl)oxy)-acetamide (OHPY 1a) and N-((3,4dimethyl-5-oxo-1-phenyl-4,5-dihydro-1H-pyrazol-4-yl)oxy)-acetamide (OHPY 1b): To a solution of acetohydroxamic acid $(1 \mathrm{mmol})$ in dimethylformamide $(3 \mathrm{~mL})$ at room temperature was added sodium hydride, $60 \%(1.1 \mathrm{mmol})$, and the reaction stirred for one hour. This solution was added to a solution of $1 \mathrm{mmol}$ of brominated pyrazolone (4(acetyl-O-methoxyoxime)-4-bromo-3-methyl-1-phenyl-pyrazolone for the synthesis of OHPY 1a and 4-bromo-3,4-dimethyl-1-phenyl-pyrazolone for the synthesis of OHPY 1b) in dimethylformamide $(2 \mathrm{~mL})$, and the reaction proceeded at room temperature for 3 hours. The reaction was diluted with ether $(20 \mathrm{~mL})$ and washed with ammonium chloride, water, and brine. The organic phase was collected, dried over magnesium sulphate $\left(\mathrm{MgSO}_{4}\right)$, and concentrated in vacuo. Recrystallization from dichloromethane and hexane gave the product OHPY 1a $(25 \%$ yield) and, following purification by flash chromatography (30\% ethylacetate/hexane) on silica gel, OHPY $\mathbf{1 b}$ ( $28 \%$ yield).

General procedure for the synthesis of N-((4-(acetyl-O-methoxyoxime)-3-methyl5-oxo-1-phenyl-4,5-dihydro-1H-pyrazol-4-yl)oxy)-methylcarbamate (OHPY 1c), N-((4(acetyl-O-methoxyoxime)-1,3-dimethyl-5-oxo-4,5-dihydro-1H-pyrazol-4-yl)oxy)-

methylcarbamate (OHPY 1d), and N-(4-(acetyl-O-methoxyoxime)-3-methyl-5-oxo-1phenyl-4,5-dihydro-1H-pyrazol-4-yl)oxy)-tert-butylcarbamate (OHPY 1e): To a solution of $1 \mathrm{mmol}$ of hydroxamic acid (C-methoxycarbohydroxamic acid for the synthesis OHPY 1c and 1d, and tert-butylhydroxycarbamate for the synthesis of OHPY 1e) in acetonitrile $(3 \mathrm{~mL})$ at room temperature was added triethylamine $(1 \mathrm{mmol})$, and the 
reaction stirred for one hour. This solution was added to a solution of $1 \mathrm{mmol}$ of brominated pyrazolone 4-(acetyl-O-methoxyoxime)-4-bromo-3-methyl-1-phenylpyrazolone for the synthesis of OHPY 1c and 1e, and 4-(acetyl-O-methoxyoxime)-4bromo-1,3-dimethyl-pyrazolone for the synthesis of OHPY 1d) in acetonitrile $(2 \mathrm{~mL})$, and the reaction proceeded at room temperature for 3 hours. The reaction mixture was concentrated via rotary evaporation, redissolved in dichloromethane, and washed with water and brine. The organic phase was collected, dried over $\mathrm{MgSO}_{4}$, and concentrated in vacuo. The compound was purified by flash chromatography $(20 \%$ ethylacetate/hexane) on silica gel to give OHPY 1c, 1d, and 1e with yields of 34\%, 28\%, and $37 \%$, respectively.

Synthesis of N-hydroxy-N-(3,4-dimethyl-5-oxo-1-phenyl-4,5-dihydro-1H-pyrazol4-yl)-N-acetamide (NHPY $3 \boldsymbol{b}$ ): To a solution of acetohydroxamic acid (210 mg, 2.80 mmol) and pyrazolone $\mathbf{2 b}(105 \mathrm{mg}, 0.56 \mathrm{mmol})$ in $50 \%$ aqueous ethanol $(7 \mathrm{~mL})$, was added potassium carbonate $(12 \mathrm{mg}, 0.09 \mathrm{mmol})$ to adjust the $\mathrm{pH}$ to $7-8$. Sodium periodate $(599 \mathrm{mg}, 2.80 \mathrm{mmol}$ ) was added to the reaction mixture, which was sonicated for $10 \mathrm{~min}$, and then stirred for $3 \mathrm{~h}$ at room temperature. The reaction mixture was diluted with ethanol $(12 \mathrm{~mL})$ and the solid was filtered. The filtrate was concentrated via rotary evaporation and the resulting solid was redissolved in ethylacetate $(50 \mathrm{~mL})$ and washed three times with a saturated solution of ammonium chloride $(30 \mathrm{~mL})$. The organic phase was collected, dried over $\mathrm{MgSO}_{4}$, and concentrated in vacuo. Recrystallization from dichloromethane and hexane gave the title compound (73\% yield). 


\subsection{Compound Characterization}

N-((4-(Acetyl-O-methoxyoxime)-3-methyl-5-oxo-1-phenyl-4,5-dihydro-1H-

pyrazol-4-yl)oxy)-acetamide (OHPY 1a): Colorless crystals, m.p. $143-145{ }^{\circ} \mathrm{C} ; \quad{ }^{1} \mathrm{H}$ NMR (400 MHz, $\left.\mathrm{CDCl}_{3}\right) \delta: 8.96(1 \mathrm{H}, \mathrm{s}, \mathrm{OH}), 7.85-7.83(2 \mathrm{H}, \mathrm{m}, \operatorname{arom}), 7.41-7.38(2 \mathrm{H}$, m, arom), 7.22-7.20 (1H, m, arom), $3.90(3 \mathrm{H}, \mathrm{s}, \mathrm{Me}), 2.34(3 \mathrm{H}, \mathrm{s}, \mathrm{Me}), 2.06(3 \mathrm{H}, \mathrm{s}, \mathrm{Me})$, $1.92(3 \mathrm{H}, \mathrm{s}, \mathrm{Me}) .{ }^{13} \mathrm{C} \mathrm{NMR}\left(100 \mathrm{MHz}, \mathrm{CDCl}_{3}\right) \quad \delta: 167.5,158.1,156.7,150.8,137.8$, 129.1, 125.7, 119.1, 90.2, 62.5, 20.0, 16.4, 10.2. HR-MS (FAB): found $m / z=319.14094$ $\left(\mathrm{MH}^{+}\right)$; calc. for $\mathrm{C}_{15} \mathrm{H}_{19} \mathrm{~N}_{4} \mathrm{O}_{4}: 319.14063$.

\section{$N$-((3,4-Dimethyl-5-oxo-1-phenyl-4,5-dihydro-1H-pyrazol-4-yl)oxy)-}

acetamide (OHPY 1b): White solid, m.p. $142-144{ }^{\circ} \mathrm{C} ;{ }^{1} \mathrm{H}$ NMR $\left(400 \mathrm{MHz}, \mathrm{CDCl}_{3}\right) \delta$ : $9.07(1 \mathrm{H}, \mathrm{s}, \mathrm{OH}), 7.90-7.88(2 \mathrm{H}, \mathrm{m}$, arom), 7.44-7.41 (2H, m, arom), 7.23-7.25 (1H, m, arom), $2.34(3 \mathrm{H}, \mathrm{s}, \mathrm{Me}), 1.92(3 \mathrm{H}, \mathrm{s}, \mathrm{Me}), 1.56(3 \mathrm{H}, \mathrm{s}, \mathrm{Me}) .{ }^{13} \mathrm{C} \mathrm{NMR}(100 \mathrm{MHz}$, $\left.\mathrm{CDCl}_{3}\right) \delta: 170.6,161.3,158.1,137.5,132.1,129.1,125.6,118.4,87.6,20.4,18.5,13.2$. HR-MS (FAB): found $m / z=262.11949\left(\mathrm{MH}^{+}\right)$; calc. for $\mathrm{C}_{13} \mathrm{H}_{15} \mathrm{~N}_{3} \mathrm{O}_{3}: 262.11917$.

\section{$N$-((4-(Acetyl-O-methoxyoxime)-3-methyl-5-oxo-1-phenyl-4,5-dihydro-1H-}

pyrazol-4-yl)oxy)-methylcarbamate (OHPY 1c): White solid, m.p. $128-130{ }^{\circ} \mathrm{C} ;{ }^{1} \mathrm{H}$ NMR (400 MHz, $\left.\mathrm{CDCl}_{3}\right)$ 8: 7.92-7.90 (2H, m, arom), $7.50(1 \mathrm{H}, \mathrm{s}, \mathrm{OH}), 7.41-7.44(2 \mathrm{H}$, m, arom), 7.20-7.22 (1H, m, arom), $3.90(3 \mathrm{H}, \mathrm{s}, \mathrm{Me}), 3.77(3 \mathrm{H}, \mathrm{s}, \mathrm{Me}), 2.38(3 \mathrm{H}, \mathrm{s}, \mathrm{Me})$, $2.08(3 \mathrm{H}, \mathrm{s}, \mathrm{Me}) .{ }^{13} \mathrm{C} \mathrm{NMR}\left(100 \mathrm{MHz}, \mathrm{CDCl}_{3}\right) \delta: 166.8,158.8,157.3,151.3,137.4$, 129.2, 125.3, 118.7, 89.8, 62.8, 53.8, 14.9, 10.0. HR-MS (FAB): found $m / z=335.13496$ 
$\left(\mathrm{MH}^{+}\right)$; calc. for $\mathrm{C}_{15} \mathrm{H}_{19} \mathrm{~N}_{4} \mathrm{O}_{5}: 335.13554$.

$N$-((4-(Acetyl-O-methoxyoxime)-1,3-dimethyl-5-oxo-4,5-dihydro-1H-pyrazol4-yl)oxy)-methylcarbamate (OHPY 1d): White solid; ${ }^{1} \mathrm{H} \mathrm{NMR}\left(400 \mathrm{MHz}, \mathrm{CDCl}_{3}\right) \delta$ : $7.52(1 \mathrm{H}, \mathrm{s}, \mathrm{OH}), 3.89$ (3H, s, Me), 3.79 (3H, s, Me), $3.28(3 \mathrm{H}, \mathrm{s}, \mathrm{Me}), 2.27(3 \mathrm{H}, \mathrm{s}, \mathrm{Me})$,

$2.03(3 \mathrm{H}, \mathrm{s}, \mathrm{Me}) .{ }^{13} \mathrm{C} \mathrm{NMR}\left(100 \mathrm{MHz}, \mathrm{CDCl}_{3}\right) \delta: 168.6,158.3,157.6,151.1,88.9,62.5$, 53.3, 31.4, 15.0, 10.3. HR-MS (FAB): found $\mathrm{m} / \mathrm{z}=273.12013\left(\mathrm{MH}^{+}\right)$; calc. for $\mathrm{C}_{10} \mathrm{H}_{17} \mathrm{~N}_{4} \mathrm{O}_{5}: 273.11989$.

$N$-((4-(Acetyl-O-methoxyoxime)-3-methyl-5-oxo-1-phenyl-4,5-dihydro-1Hpyrazol-4-yl)oxy)-tert-butylcarbamate (OHPY 1e): White solid, m.p. 102-104 ${ }^{\circ} \mathrm{C} ;{ }^{1} \mathrm{H}$

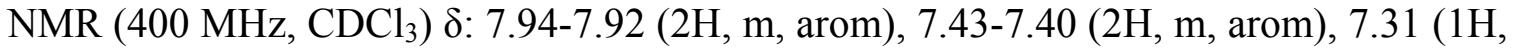
s, OH), 7.23-7.21 (1H, m, arom), $3.91(3 \mathrm{H}, \mathrm{s}, \mathrm{Me}), 2.36(3 \mathrm{H}, \mathrm{s}, \mathrm{Me}), 2.06(3 \mathrm{H}, \mathrm{s}, \mathrm{Me})$, $1.46(1 \mathrm{H}, \mathrm{s}, \mathrm{C}(\mathrm{Me}) 3) .{ }^{13} \mathrm{C} \mathrm{NMR}\left(100 \mathrm{MHz}, \mathrm{CDCl}_{3}\right) \delta: 167.3,159.4,156.1,151.2,137.8$, 129.2, 125.3, 118.4, 89.8, 82.9, 62.4, 28.0, 15.1, 10.2. HR-MS (FAB): found $\mathrm{m} / \mathrm{z}=$ $377.18180\left(\mathrm{MH}^{+}\right)$; calc. for $\mathrm{C}_{18} \mathrm{H}_{25} \mathrm{~N}_{4} \mathrm{O}_{5}: 377.18250$.

\section{$N$-Hydroxy- $N$-(3,4-dimethyl-5-oxo-1-phenyl-4,5-dihydro-1H-pyrazol-4-yl)- $N$ -} acetamide (NHPY 3b): White solid; ${ }^{1} \mathrm{H}$ NMR (400 MHz, $\left.\mathrm{CDCl}_{3}\right) \delta: 9.08(1 \mathrm{H}, \mathrm{s}, \mathrm{OH})$, 7.87-7.85 (2H, m, arom), 7.45-7.43 (2H, m, arom), 7.24-7.22 (1H, m, arom), $2.18(3 \mathrm{H}, \mathrm{s}$, Me), $2.10(3 \mathrm{H}, \mathrm{s}, \mathrm{Me}), 1.68(3 \mathrm{H}, \mathrm{s}, \mathrm{Me}) .{ }^{13} \mathrm{C} \mathrm{NMR}\left(100 \mathrm{MHz}, \mathrm{CDCl}_{3}\right) \delta: 167.8,159.0$, 157.2, 151.4, 137.5, 127.9, 125.8, 119.5, 72.3, 22.5, 19.2, 12.4. HR-MS (FAB): found $m / z=262.11917\left(\mathrm{MH}^{+}\right)$; calc. for $\mathrm{C}_{13} \mathrm{H}_{15} \mathrm{~N}_{3} \mathrm{O}_{3}: 262.11981$. 


\section{Acknowledgments}

We gratefully acknowledge the National Science Foundation (CHE-1213438) and Cardioxyl Pharmaceuticals for generous support of this research. We also thank the Johns Hopkins Department of Chemistry Facility Managers, Dr. Maxime A. Siegler (Xray Crystallography), and Dr. I. Phil Mortimer (Mass Spectrometry) for assistance with compound identification and characterization.

\section{Supplementary Material}

Crystallographic data of OHPY 1a (CCDC 1495947) and NHPY 3b (CCDC 1495948) have been deposited at the Cambridge Crystallographic Database Centre. These data can be obtained for free via https://www.ccdc.cam.ac.uk/. Supplementary data associated with this article can be found in the online version, at http://dx.doi.org/

\section{Notes}

The authors declare the following competing financial interest(s): J.P.T. was a co-founder, stockholder, and served on the Scientific Advisory Board of Cardioxyl Pharmaceuticals. 


\section{References}

1. Paolocci, N.; Saavedra, W. F.; Miranda, K. M.; Martignani, C.; Isoda, T.; Hare, J. M.; Espey, M. G.; Fukuto, J. M.; Feelisch, M.; Wink, D. A.; Kass, D. A. Proc. Natl. Acad. Sci. U.S.A. 2001, 98, 10463-10468.

2. Paolocci, N.; Katori, T.; Champion, H. C.; St. John, M. E.; Miranda, K. M.; Fukuto, J. M.; Wink, D. A.; Kass, D. A. Proc. Natl. Acad. Sci. U.S.A. 2003, 100, $5537-5542$.

3. Dai, T.; Tian, Y.; Tocchetti, C. G.; Katori, T.; Murphy, A. M.; Kass, D. A.; Paolocci, N.; Gao, W. D. J. Physiol. 2007, 580, 951-960.

4. Tocchetti, C. G.; Wang, W.; Froehlich, J. P.; Huke, S.; Aon, M. A.; Wilson, G. M.; Di Benedetto, G.; O’Rourke, B.; Gao, W. D.; Wink, D. A.; Toscano, J. P.; Zaccolo, M.; Bers, D. M.; Valdivia, H. H.; Cheng, H.; Kass, D. A.; Paolocci, N. Circ. Res. 2007, 100, 96-104.

5. Tocchetti, C. G.; Stanley, B. A.; Murray, C. I.; Sivakumaran, V.; Donzelli, S.; Mancardi, D.; Pagliaro, P.; Gao, W. D.; van Eyk, J.; Kass, D. A.; Wink, D. A.; Paolocci, N. Antioxid. Redox Signal. 2011, 14, 1687-1698.

6. Kemp-Harper, B. K. Antioxid. Redox Signal. 2011, 14, 1609-1616.

7. Flores-Santana, W.; Salmon, D. J.; Donzelli, S.; Switzer, C. H.; Basudhar, D.; Ridnour, L.; Cheng, R.; Glynn, S. A.; Paolocci, N.; Fukuto, J. M.; Miranda, K. M.; Wink, D. A. Antioxid. Redox Signal. 2011, 14, 1659-1674.

8. Sabbah, H. N.; Tocchetti, C. G.; Wang, M.; Daya, S.; Gupta, R. C.; Tunin, R. S.; Mazhari, R.; Takimoto, E.; Paolocci, N.; Cowart, D.; Colucci, W. S.; Kass, D. A. Circ. Hear. Fail. 2013, 6, 1250-1258.

9. Arcaro, A.; Lembo, G.; Tocchetti, C. G. Curr. Heart Fail. Rep. 2014, 11, 227235.

10. Shafirovich, V.; Lymar, S. V. Proc. Natl. Acad. Sci. U.S.A. 2002, 99, 7340-7345.

11. Hughes, M. N.; Cammack, R. Methods Enzymol. 1999, 301, 279-287.

12. Porcheddu, A.; De Luca, L.; Giacomelli, G. Synlett 2009, 13, 2149-2153.

13. Sirsalmath, K.; Suárez, S. A.; Bikiel, D. E.; Doctorovich, F. J. Inorg. Biochem. 2013, 118, 134-139. 
14. Toscano, J. P.; Brokkfield, F. A.; Cohen, A. D.; Courtney, S. M.; Frost, L. M.; Kalish, V. J. U.S. Patent 8,030,356, 2011.

15. Sutton, A. D.; Williamson, M.; Weismiller, H.; Toscano, J. P. Org. Lett. 2012, 14, $472-475$.

16. Sha, X.; Isbell, T. S.; Patel, R. P.; Day, C. S.; King, S. B. J. Am. Chem. Soc. 2006, 128, 9687-9692.

17. Shoman, M. E.; DuMond, J. F.; Isbell, T. S.; Crawford, J. H.; Brandon, A.; Honovar, J.; Vitturi, D. A.; White, C. R.; Patel, R. P.; King, S. B. J. Med. Chem. 2011, 54, 1059-1070.

18. Guthrie, D. A.; Kim, N. Y.; Siegler, M. A.; Moore, C. D.; Toscano, J. P. J. Am. Chem. Soc. 2012, 134, 1962-1965.

19. Guthrie, D. A.; Ho, A.; Takahashi, C. G.; Collins, A.; Morris, M.; Toscano, J. P. J. Org. Chem. 2015, 80, 1338-1348.

20. Guthrie, D. A.; Nourian, S.; Takahashi, C. G.; Toscano, J. P. J. Org. Chem. 2015, 80, 1349-1356.

21. Atkinson, R. N.; Storey, B. M.; King, S. B. Tetrahedron Lett. 1996, 37, 92879290.

22. Miao, Z.; King, B. Nitric Oxide 2016, 57, 1-14.

23. Kirby G. W., Sweeny J. G. J. Chem. Soc. Perkin Trans. I. 1981, 3250-3254.

24. Corrie J. E. T., Kirby G. W., Mackinnon J. W. M. J. Chem. Soc. Perkin Trans. I. 1985, 883-886.

25. Zeng, B; Huang, J.; Wright, M. W.; King, S. B. Bioorg. Med. Chem. 2004, 14, $5565-5568$.

26. Quadrelli, P.; Mella, M.; Caramella, P. Tetrahedron Lett. $\square$ 1999, 40, 797-800.

27. O'Bannon, P. E.; William, D. P. Tetrahedron Lett. 1988, 29, 5719-5722.

28. Evans, A. S; Cohen, A. D.; Gurard-Levin, Z. A.; Kebede, N.; Celius T. C.; Miceli, A. P.; Toscano, J. P. Can. J. Chem. 2011, 89, 130-138.

29. Frazier, C. P.; Engelking, J. R.; Read de Alaniz, J. J. Am. Chem. Soc. 2011, 133, 10430-10433.

30. Fakhruddin, A.; Iwasa, S.; Nishiyama, H.; Tsutsumi, K. Tetrahedron Lett. 2004, 45, 9323-9326. 
31. Yamamoto, Y.; Yamamoto, H. European J. Org. Chem. 2006, 2006, 2031-2043.

32. Chaiyaveij, D.; Cleary, L.; Batsanov, A. S.; Marder, T. B.; Shea, K. J.; Whiting, A. Org. Lett. 2011, 13, 3442-3445.

33. Sandoval, D.; Frazier, C. P.; Bugarin, A.; Read de Alaniz, J. J. Am. Chem. Soc. 2012, 134, 18948-18951.

34. Baidya, M.; Griffin, K. A.; Yamamoto, H. J. Am. Chem. Soc. 2012, 134, 1856618569.

35. Selig, P. Angew. Chemie Int. Ed. 2013, 52, 7080-7082.

36. Palmer, L.; Frazier, C.; Read de Alaniz, J. Synthesis. 2013, 46, 269-280.

37. Baidya, M.; Yamamoto, H. Synthesis. 2013, 45, 1931-1938.

38. Frazier, C. P.; Sandoval, D.; Palmer, L. I.; Read de Alaniz, J. Chem. Sci. 2013, 4, $3857-3862$.

39. Yang, W.; Huang, L.; Yu, Y.; Pflasterer, D.; Rominger, F.; Hashmi, S. K. Chem. Eur. J. 2014, 20, 3927-3931.

40. Yu, C.; Song, A.; Zhang, F. Wang, W. ChemCatChem. 2014, 6, 1863-1865.

41. Sandoval, D.; Samoshin, A. V; Read de Alaniz, J. Org. Lett. 2015, 17, 45144517.

42. Ramakrishna, I.; Grandhi, G. S.; Sahoo, H.; Baidya, M. Chem. Commun. 2015, 51, 13976-13979.

43. Maji, B.; Yamamoto, H. Angew. Chem. 2014, 126, 14700-14703.

44. Maji, B.; Yamamoto, H. Bull. Chem. Soc. Jpn. 2015, 88, 753-762.

45. Xu, C.; Zhang, L.; Luo, S. Angew. Chem. Int. Ed. 2014, 53, 4149-4153.

46. Merino, P.; Tejero, T.; Delso, I.; Matute, R. Synthesis 2016, 48, 653-676.

47. Nourian, S.; Zilber, Z. A.; Toscano, J. P. "Development of $\mathrm{N}$-Substituted Hydroxamic Acids with Pyrazolone Leaving Groups as Nitrosocarbonyl Precursors", manuscript under review.

48. Steinberg, G. M.; Bolger, J. J. Org. Chem. 1956, 21, 660-662.

49. Glover, S. A. In The Chemistry of Hydroxylamines, Oximes, and Hydroxamic Acids, Part 2; Rappoport, Z., Liebman, J. F., Eds.; John Wiley \& Sons: Chichester, West Sussex, 2009, p 839-923. 
50. Defoin, A.; Fritz, H.; Schmidlin, C.; Streith, J. Helv. Chim. Acta 1987, 70, 554 569. 


\section{Graphical Abstract}

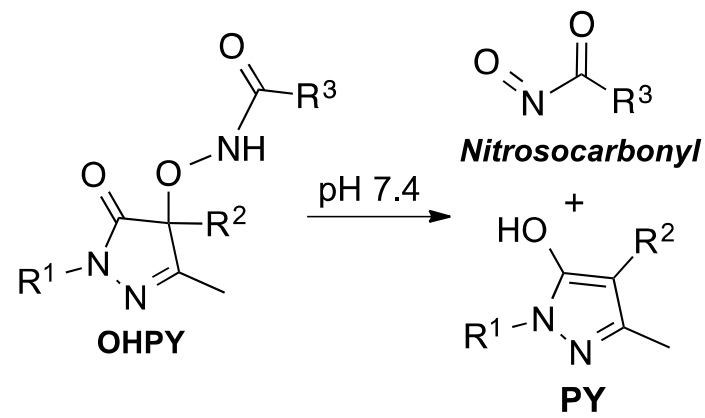

